Максимальное расхождение между параметрами наблюдалось в критическом сечении камеры в большую сторону относительно стандартной методики.

Выводы. В данной работе приведено численное решение системы одномерных дифференциальных уравнений газовой динамики и теплового баланса для камеры ЖРД. В результате расчета в каждом сечении камеры определены параметры газового потока продуктов сгорания, удельные тепловые потоки, температура стенки камеры и температура жидкого охладителя.

Расхождение со стандартной методикой обусловлено учетом распределения газодинамических параметров по длине камеры сгорания и их влияния на процесс охлаждения. Таким образом, можно сделать вывод, что в данной работе получены более точные результаты по сравнению с расчетом охлаждения, выполненного с помощью стандартной методики.

\section{Библиографические ссылки}

1. Теория ракетных двигателей : учебник для студ. машиностроительных спец. вузов. Под ред. В. П. Глушко, В. Е. Алемасова, А. Ф. Дрегалина, А. П. Тишина. Москва : Машиностроение, $1980.533 \mathrm{c}$.

2. Добровольский М. В. Жидкостные ракетные двигатели. Москва : Машиностроение, 1968. 396 с.

3. Лойцянский Л. Г. Механика жидкости и газа. Москва : Дрофа, 2003. $840 \mathrm{c}$.
4. Кочин Н. Е., Кибель И. А., Розе Н. В. Теоретическая гидромеханика. В 2-х ч. Ч. 2. Москва : Физматгиз, 1963. $728 \mathrm{c}$.

5. Васильев А. П. Основы теории и расчета жидкостных ракетных двигателей. Под ред. В. М. Кудрявцева. Москва : Высш. школа, 1983. 703 с.

6. Михеев М. А. Основы теплопередачи. Москва : Энергия, 1977. $345 \mathrm{c}$.

7. Варгафтик Н. Б. Справочник по теплофизическим свойствам газов и жидкостей. Москва : Наука, 1972. 721 с.

8. Андерсон Д., Таннехил Дж., Плетчер Р. Вычислительная гидромеханика и теплообмен. Пер. с англ. В 2-х т. Т. 1. Москва : Мир, 1990. 384 с.

9. Changqing $\mathrm{Hu}$, Chi-Wang Shu. Weighted Essentially Non-oscillatory Schemes on Triangular Meshes. Journal of Computational Physics. Vol. 150. Issue 1. 1999. P. 97-127.

10. Wang, Qian \& Ren, Yu-Xin \& Lee, Marka (2016). Compact high order finite volume method on unstructured grids I: Basic formulations and one-dimensional schemes. Journal of Computational Physics. 314. 10.1016/j.jcp.2016.01.036.

11. Gottlieb S. and Shu C.-W. Total variation diminishing Runge-Kuttaschemes: Math. Comp., 67. 1998. P. 73-85.

12. Калиткин Н. Н. Численные методы. Москва : Наука, 1978. 512 с.

Надійшла до редколегії 29.05.2018 р.

УДК 629.7.036.54

\title{
ПЕРСПЕКТИВНІ НАПРЯМКИ НАУКОВИХ ДОСЛІДЖЕНЬ НА КАФЕДРІ ДВИГУНОБУДУВАННЯ
}

\author{
М. О. Катренко, С. Г. Бондаренко, О. В. Сосновська,
} О. С. Золотько, О. Л. Марченко, С. М. Подольчак

Дніпровський наџіональний університет імені Олеся Гончара, пр. Гагаріна, 72, м. Дніпро, 49010, Україна, e-mail: arush@ua.fm

Подано ретроспективу напрямків наукових досліджень співробітників кафедри двигунобудування фізико-технічного факультету. Розглянуто історичне становлення та розвиток, здобутки вчених кафедри в галузі ракетного двигунобудування, а також перспективи їх подальших досліджень.

Ключові слова: напрямок, перспективи, дослідження, ракетні двигуни, актуальність. 
A retrospective of directions of scientific researches of employees of the chair of engine-building of physical-technical faculty is presented. The historical formation and development, achievements of the faculty's scientists in the field of rocket engine construction, as well as prospects for their further research are considered.

Keywords: direction, prospects, research, rocket engines, relevance.

Представлена ретроспектива направлений научных исследований сотрудников кафедры двигателестроения физико-технического факультета. Рассмотрены историческое становление и развитие, достижения ученых кафедры в области ракетного двигателестроения, а также перспективы их дальнейших исследований.

Ключевые слова: направление, перспективы, исследования, ракетные двигатели, актуальность.

Вступ. Співробітники кафедри двигунобудування фізико-технічного факультету Дніпровського національного університету ім. О. Гончара зробили вагомий внесок у досягнення університету в науковій та педагогічній сферах. Багатогранність наукових напрямків у галузі ракетної техніки та отриманих досягнень визначали неординарні діячі науки, історичні особистості.

Метою досліджень $\epsilon$ стислий аналіз пріоритетних напрямків діяльності наукової школи кафедри двигунобудування фізико-технічного факультету Дніпровського національного університету ім. О. Гончара, їх становлення, історичний розвиток та перспективи міжнародної співпраці, а також пригадати та віддати шану наполегливій праці вчених, які самовіддано працювали на кафедрі двигунобудування.

Основна частина та обговорення. На початку 1990-х рр. на кафедрі було створено розвинену високотехнологічну експериментальну базу 3 дослідження фізики кипіння рідини у діапазоні від кріогенних температур до температур кипіння лужних металів. Основна увага приділялася дослідженню мікрохарактеристик пузирчастого кипіння ракетних палив. За допомогою нових теоретичних моделей проводилися розрахунки тепломасообмінних процесів 3 фазовими переходами у системі живлення рідинного ракетного двигуна. Вагомий науковий внесок у цьому напрямку належить академіку НАН України В.Ф. Пріснякову, професорам B.M. Серебрянському, П.П. Падуну, Ю.В. Морозову, О.В. Січевому, доцентам В.В. Покришкіну, Ю.К. Гонтарєву, С.Г. Бондаренку, С.О. Білогурову, о.Є. Золотьку, Н.В. Сітніковій, Ю.В. Наврузову, В.І. Луценку,
В.М. Сідушкіну, Н.О. Носачу, с.н.с. С. В. Ткаченку.

Починаючи 3 2000-х рр. співробітники кафедри у плідній співпраці зі співробітниками відділу термогазодинаміки ракетно-космічних двигунів і енергетичних установок Інституту технічної механіки Національної академії наук України, яку очолював видатний учений професор М.Д. Коваленко, приступили до розробки теоретичних основ створення новітнього покоління ракетних та реактивних двигунів, що працюють за детонаційним робочим циклом. Перехід від традиційного циклу 3 постійним тиском у камері згоряння (циклу Брайтона) до детонаційного забезпечує максимальну термодинамічну ефективність, значний виграш у льотно-технічних характеристиках та високу ступінь конструктивної досконалості перспективних двигунних установок [10]. За останні майже п'ятнадцять років вирішено ряд принципових науково-технічних задач, створено проблемно-орієнтований пакет комп'ютерних прикладних програм, який дозволяе проводити обчислювально-експериментальні дослідження визначальних параметрів детонаційних двигунів та механізмів керування високошвидкісними потоками продуктів детонації.

Актуальність досліджень імпульсного детонаційного двигуна 3 ежекторним підсилювачем тяги визначається доведеною можливістю істотного поліпшення характеристик двигунної установки імпульсної (періодичної) дії за рахунок використання в якості приєднаної маси атмосферного повітря. Розробка конструкції детонаційного двигуна 3 ежектором $\epsilon$ одним із пріоритетних напрямків розвитку ракетно-космічного двигунобудування. 
Завдяки невеликим габаритам, простоті конструкції та іншим перевагам ежекторні пристрої отримали розповсюдження в різних галузях промисловості. Детально розглянуто конструктивні схеми одноступінчастих, багатоступінчастих, багатосоплових, вихрових та інших ежекторів. Проведено порівняльний аналіз та визначено основні переваги та недоліки ежекторів різних схем. Вирішено задачу вибору оптимального ежектора для детонаційної камери імпульсного двигуна. Між реактивним струменем, що витікає з камери двигуна, та потоком повітря, що проходить через ежектор, відбувається обмін кількістю руху.

Існує оптимальна швидкість польоту Мळ, при якій можливості ежекторного сопла реалізуються в повному обсязі. Вплив конструктивних параметрів і режимних факторів на імпульсні характеристики детонаційного двигуна 3 ежектором досліджено методом обчислювального експерименту. Підвищення імпульсних характеристик обумовлено взаємодією потоку продуктів детонації зі стінками ежектору та збільшенням часу перебування продуктів детонації в проточній частині двигуна.

Нестаціонарний ежектор здатний продукувати збільшення тяги у порівнянні 3 традиційним стаціонарним. Завдяки високій ефективності процесу передачі енергії первинним потоком вторинному в процесі його взаємодії 3 вихровими структурами, які виникають за лідируючою ударною хвилею, посилюються характеристики нестаціонарного ежектора. При дифракції ударної хвилі на виході 3 детонаційної камери утворюються нестаціонарні обертові вихрові кільця.

Досліджено оптимальне розміщення ежектора відносно камери детонаційного двигуна для досягнення максимального значення збільшення коефіцієнта підсилення тяги. Найбільшою мірою впливають на величину питомого імпульсу тяги двигуна геометричні параметри ежектора. Дослідження показують, що характеристики ежектора чутливі до осьового положення вхідного пристрою ежектора щодо вихідного перетину детонаційної камери двигуна, при осьовому зміщенні ежектора вниз за течією потоку він забезпечує значно кращі характеристики, ніж у разі його зміщення вгору за течією [15].

Окрім інших переваг, використання ежектора позитивно впливає на зниження шуму двигунної установки та дозволяє зменшити забруднення навколишнього середовища. Перспективи подальших досліджень пов'язані 3 вивченням та оцінкою імпульсної детонації 3 використанням альтернативних видів палива, оскільки останнім часом основна увага наукової спільноти приділяється екологічній безпеці навколишнього середовища.

Важливим напрямком наукової діяльності кафедри двигунобудування, 3 урахуванням потреб базових підприємств $\epsilon$ галузь систем постачання компонентів палива ракетних двигунів. Біля витоків наукової школи теорії та проектування агрегатів систем постачання компонентів палива ракетних двигунів на кафедрі двигунобудування були доценти Ю.В. Дронов, В.І. Місюра. Ю.В. Дронов, випускник Казанського авіаційного інституту, за свій виробничий, науковий та педагогічний шлях на кафедрі створив лабораторію лопатевих машин, яка 3 1976 р. була перейменована у лабораторію теплосилових установок, де проводилися дослідження суміщених систем постачання i розпилу рідин у РРД і теплогенераторах, розроблялися нові технічні рішення на основі експериментальних i теоретичних досліджень робочих характеристик пористих розпилювачів, лопатевих насосів, експериментальні дослідження космічних мікронасосів для систем життєзабезпечення космічних апаратів [14]. Ю.В. Дронов опублікував багато наукових статей, він $\epsilon$ автором важливих методичних праць у галузі проектування турбонасосних агрегатів РРД та систем постачання палива. Вагомий внесок у наукові дослідження в цій галузі вніс В.І. Місюра, співавтор монографії разом з Б.В. Овсянніковим, В.Ф. Прісняковим по дискових насосах, яка i по нинішній час $\epsilon$ майже єдиною 
фундаментальною роботою по цій тематиці. Важливість дослідження течії рідини у гідравлічних машинах тертя, дослідження кавітаційних властивостей відцентрових насосів тертя довели їх високі технічні характеристики, розкрили нові області їх використання в ракетнокосмічній і других видах техніки [14; 13]. B.I. Мiсюра у творчій співдружності 3 Ю.В. Дроновим були науковими наставниками багатьох вчених, які надалі працювали на кафедрі двигунобудування, серед яких доц. Г.А. Горбенко, M.O Катренко, провідний науковий співробітник А.А. Панченко та інші.

Доцент Г.А. Горбенко закінчила Дніпропетровський державний університет, має величезний технічний досвід проектування насосних систем у ДКБ «Південне», займалася підготовкою спеціалістів у галузі двигунобудування. Г.А. Горбенко відомий спеціаліст у проектуванні, випробуваннях вихрових насосів, систем постачання компонентів палива ракетних двигунів, має наукові розробки та публікації, вона $\epsilon$ автором методичних та довідкових робіт, які використовуються в навчальному процесі на кафедрі двигунобудування.

Створенням матеріально-технічної бази для організації якісного навчання, та наукових досліджень у галузі агрегатів систем постачання займався провідний науковий співробітник А.А. Панченко. У співавторстві з академіком В.Ф. Прісняковим, доцентом Ю.В. Дроновим проводив дослідження енергетичних установок на рідких металах, відцентрових насосів 3 пористими кільцями, в результаті чого отримав унікальні технічні результати, які втілилися в наукових статтях, доповідях та охоронних документах. За його участі створено лабораторні установки для дослідження характеристик та процесів у насосах різноманітних типів. А.А. Панченко займався питаннями проектування не тільки двигунів та двигунних установок, а і теплоенергетичних установок, теплообмінників, компресорів, спецконструкцій, систем постачання. Під його керівництвом на створеній експериментальній базі було проведено експериментальні дослідження щіткових ущільнень, результати яких було використано на АТ «Мотор Січ». А.А. Панченко $\epsilon$ автором багатьох авторських свідоцтв, наукових робіт, які мають велике практичне значення в галузі ракетної техніки та народного господарства. Дослідження процесів в агрегатах для отримання газопарових середовищ та розробка й виготовлення теплогенераторів для промислових потреб, що працюють як на твердому, так i на газоподібному паливі, під керівництвом А.А. Панченка, у промислових умовах на деяких підприємствах будівельної індустрії, підприємств, що спеціалізуються на переробці сільськогосподарської продукції, довело їх економічність, необхідність та заповнило область теплоенергетичного устаткування на вторинних ресурсах.

Проблемою надійності ракетних двигунів на кафедрі двигунобудування почали займатися майже 3 початку іï заснування, так як у той час на кафедрі працювало багато співробітників ДП «КБ «Південне» ім. М. К. Янгеля». Але засновником наукового напряму «Теорія надійності ракетних двигунів на рідкому паливі» можна повною мірою вважати професора кафедри двигунобудування Людмилу Володимирівну Пронь. Адже саме група співробітників ДП «КБ «Південне» ім. М. К. Янгеля», до якої входила і Людмила Володимирівна, вперше провела розрахунки по наближенню умов стендових випробувань до льотних та по установленню причин виникнення відмов ракетного двигуна під час випробувань. У подальшому, вже працюючи на кафедрі, Л.В. Пронь продовжила дослідження по експериментальному відпрацюванню РД на рідкому паливі. По даній тематиці було укладено договори про співпрацю між ДП «КБ «Південне» ім. М. К. Янгеля» та університетом, за результатами яких було випущено декілька технічних звітів та дві монографії «Теоретические основы экспериментальной отработки ЖРД» та «Летные испытания ЖРД», співавтором яких є Людмила Володимирівна.

Пізніше до наукових досліджень 3 надійності ракетних двигунів приєднався 
старший

викладач

кафедри

C.M. Подольчак, який за договором про співпрацю між університетом та ДП «КБ «Південне» ім. М.К. Янгеля» почав займатися дослідженнями випробувань РД на надійність. Тісна співпраця Л.В. Пронь та С.M. Подольчака дала можливість впровадити результати своїх досліджень у навчальний процес для підготовки майбутніх фахівців у ракетно-космічній галузі. Було видано ряд навчальних посібників: «Методологічні основи випробувань ракетних двигунів», «Засоби вимірювань під час випробувань ракетних двигунів» та «Основи теорії надійності ракетних двигунів».

Було проведено дослідження по взаємодії системи аварійного захисту (САЗ) й ракетного двигуна при стендових випробуваннях 3 точки зору доцільності використання САЗ залежно від рівня надійності ракетного двигуна [6]. Також проведено аналіз ефективності існуючих програм випробувань РД на надійність та проведено структурний аналіз програми прискорених випробувань РД на надійність [8].

У теперішній час дослідження проблем надійності ракетних двигунів за результатами випробувань на кафедрі двигунобудування продовжуються у тісній співпраці 3 ДП «КБ «Південне» ім. М.К. Янгеля». За даною тематикою опубліковано понад 20 наукових статей та технічних звітів. Дана тема була виділена в окремі розділи двох держбюджетних тем, які вела кафедра в останні роки.

Поява разом 3 ракетною та атомною технікою різноманітних систем 3 високою енергонапруженністю найчастіше унеможливлює застосування теплоносія без зміни його агрегатного стану. Зважаючи на тенденції та перспективи розвитку вищезгаданих пристроїв, процеси кипіння, a також використання двофазних теплоносіїв виглядають досить актуально, а в деяких випадках як єдиний варіант переносу великої кількості теплової енергії.

Також слід зазначити, що при роботі високоенергетичних пристроїв можлива поява коливань i вібрацій. Проведені співробітниками кафедри дослідження показують, що наявність вібрацій значно впливає на поведінку двофазних теплоносіїв. Вібруюча поверхня теплообміну призводить до значного збільшення коефіцієнта тепловіддачі, що може бути використано для інтенсифікації процесів теплообміну.

Основною метою досліджень у цій області $€$ вивчення можливості створення двигунів без традиційної схеми охолодження шляхом безпосереднього контакту 3 паливом у баці, так званий «утоплений двигун». Перші дослідження впливу вібрацій на процеси кипіння проводилися в рамках співробітництва між ДНУ ім. О. Гончара й Інститутом геотехнічної механіки ім. Н.С. Полякова НАН України у відділі високотемпературної техніки співробітника -ми кафедри Ю.В. Наврузовим, П.В. Мамонтовим і А.В. Стойчевим під керівництвом академіка В.Ф. Пріснякова. Дослідження тривають i на цей час співробітником кафедри О.Л. Марченко під керівництвом проф. В.О. Габрінця. Результати будуть представлені в дисертаційній роботі [7].

Дослідження впливу вібрацій на тепломасообмінні процеси не обмежується тільки ракетною технікою. Так, співробітниками кафедри в результаті експериментальних досліджень доведено істотний вплив вібрацій на процеси кипіння, випару, конденсації, а також руху теплоносія в пористих каналах теплових труб. Даний напрямок $є$ перспективним, оскільки теплові трубки знаходять все більше застосування в електронних пристроях, космічних літальних апаратах та в області відновлюваної енергетики [23].

На даний момент в ракетній техніці лідируючі позиції займають рідинні ракетні двигуни (РРД) та твердопаливні ракетні двигуни (РДТП). Вони мають свої переваги і недоліки. Такою собі проміжною ланкою $\epsilon$ ракетні двигуни на пастоподібному паливі (РДПП). Такі двигуни не варто недооцінювати, адже вони мають ряд переваг перед РРД і РДТП. Ці переваги дозволяють РДПП виконувати завдання, недоступні для двигунів на інших видах палива. 
РДПП запозичує від РДТП простоту конструкції, технологічність, унітарність палива, а також більш високу питому вагу палива, ніж у рідких палив, відповідно і баки у такого двигуна будуть менше. Від РРД РДПП запозичили багаторазовість запусків, заповнення всього вільного об'єму баків паливом, поліпшені габаритно-масові характеристики. A найголовнішою перевагою РДПП є глибоке дроселювання (десятикратне i більше), при цьому регулювати тягу в такому двигуні набагато простіше, ніж у РРД, тому що якість (повнота) згоряння паливної пасти не залежить від умов іiі надходження в камеру згоряння і не змінюється при регулюванні тяги двигуна в широкому діапазоні.

Пастоподібні палива (ПП) - це незатверділі гетерогенні системи, що складаються 3 високомолекулярної зв'язки, пластифікатора як пального i твердих дисперсних частинок як окислювача. ПП це паливна паста, що складається 3 основних компонентів сучасних сумішевих (модифікованих) ракетних палив, які перемішані в заводських умовах на етапі виготовлення без добавки компонентів, що забезпечують затвердіння паливної пасти. Вважається, що одним 3 переваг виробництва такого палива $є$ те, що воно базується на використанні відпрацьованих технологій спорядження РДТП. Вони не течуть у звичайних умовах, але під впливом зовнішнього навантаження (при перепаді тиску) ПП стають текучими, а при знятті останнього вони знову набувають початкового стану. ПП належить до неньютонівських рідин, які мають мале граничне напруження зсуву, але як рідини приймають форму тієї посудини, де вони знаходяться.

ПП - це унітарні монопалива, що містять в одному об'ємі (в баку) одночасно і пальні, і окисні елементи. Через їх значно більшу в'язкість у порівнянні зі звичайними ньютонівськими рідинами їх витратні характеристики підпорядковуються іншим залежностям, відмінним від аналогічних характеристик штатних компонентів сучасних РРД. Порівняно висока в'язкість, здатність продавлюватися по каналах складної форми, седиментаційна стійкість
ПП при наявності твердих дисперсних частинок, можливість легко варіювати компонентним складом паливних композицій дозволяе більш простими способами вирішувати питання щодо підвищення швидкості горіння, питомого імпульсу, густини ПП, дроселювання тяги.

В Україні в ДП «КБ «Південне» ім. М.К. Янгеля» в 1975 році, після безуспішних спроб організувати регулювання i багаторазове включення РДТП, було розпочато роботи зі створення ракетного двигуна на пастоподібному паливі, для заміни РРД на верхніх ступенях твердопаливних ракет. Роботи велися 3 ініціативи А. I. Сердюка та за підтримки головного конструктора РДТП В.І. Кукушкіна. Проектно-конструкторські роботи і проведення випробувань РДПП проводилися А. М. Іванченком. Розробка пастоподібних палив i організація випробувань проводилося в НВО "Алтай" (Алтайський край, РФ) під керівництвом Тамари Войнаровської.

У Дніпропетровському державному університеті наукові дослідження ракетних двигунів на пастоподібному паливі проводили на кафедрах теплотехніки (нині кафедра двигунобудування), технічної механіки, тепломасообміну та прикладної газової динаміки. За цією тематикою було захищено кандидатську дисертацію інженером Л.В. Лебєдінською (наукові керівники - д.т.н., проф. М.I. Дупліщев та к.т.н. А.І. Сердюк). У 90-ті роки на кафедрі хімії та хімічної технології високомолекулярних сполук к.Х.н., доцентами О.Ф. Курочкіним та О.Б. Суровцевим зі студентами досліджувалися реологічні властивості неньютонівських рідин на прикладі пастоподібних ракетних палив.

З 2006 по 2007 рр. виконувався договір № 1259 про науково-технічне співробітництво між Дніпропетровським національним університетом та ДП «КБ «Південне» ім. М. К. Янгеля» за темою «Дослідження принципів створення, балістичної та техніко-економічної ефективності ступенів РН та КА 3 двигунами, що використовують неньютонівські рідини як компоненти 
палива». В рамках даного договору на кафедрі двигунобудування та в НДІ енергетики ДНУ к.т.н., доц. С.Г. Бондаренком, к.т.н., с.н.с. П.Г. Хорольським та провідними інженерами А.М. Іванченком та Л.В. Адамчик при участі студентів проводилися проектні дослідження ракетних двигунів різного призначення 3 примусовим постачанням у камеру згоряння пастоподібного палива.

У період з 2008 по 2010 p. виконувався міжнародний регулярний проект Українського науковотехнологічного центру (УНТЦ) № 4049 за темою «Двигунні установки на унітарному пастоподібному паливі для ступенів РН i КА». Цей проект успішно пройшов конкурсний відбір та фінансувався Єврокомісією при підтримці закордонних партнерів: Surrey Satellite Technologies Ltd., United Kingdom; MT Aerospace, Germany; Inden Cons Beratungand Consulting, Germany. Організації-учасники проекту Дніпропетровський національний університет (координуюча організація); Державне підприємство "НBO "Павлоградський хімічний завод"; приватне підприємство "СТАНДАРД" (підрозділ „Лабораторія перспективних ракетних двигунів"). Керівник проекту - к.т.н. С.Г. Бондаренко. Від ДНУ в даному проекті взяли активну участь: кандидати наук, доценти: М.В. Масляний, Д.В. Майданюк, А.Ю. Дреус, В.І. Єлісеєв, В.І. Ліповський, О.Ф. Курочкін, О.Б. Суровцев, П.Г. Хорольський, С.Ф. Лягушин, Ю.М. Мелікаєв, д.т.н., професори: М.Д. Коваленко, Г.О. Стрельніков, науковий співробітник В.П. Бабицький та технік А.І. Степченко.

Роботи за проектом УНТЦ № 4049 були проектно-конструкторського, дослідно-аналітичного і експериментального напрямку та проведені 3 метою визначення ефективності ракетних двигунних установок на пастоподібному паливі при використанні їх тільки у космічній галузі в якості маршових, розгінних, маневрових та інших двигунних установокракет-носіїв i космічних апаратів.
В результаті виконання проекту було одержано такі основні науково-технічні результати: вперше запропоновано методологію розрахунків та проектування нових типів ракетних двигунних установок, проведено проектно-розрахункові аналітичні дослідження, на базі яких запропоновано декілька нових конструктивно-компонувальних схем ракетних двигунних установок на пастоподібному паливі (РДУПП) з тягою від 40 до $80000 \mathrm{H}$, 3 можливістю їх глибокого дроселювання та багаторазовим вмиканням, спроектовано дві базові РДУПП з тягою 3 та 80 кН, визначено можливі галузі застосування РДУПП (ракети-носії, орбітальні розгінні блоки, космічні апарати, апарати для посадки на поверхню планет та Місяць, суборбітальні апарати, системи аварійного порятунку космічних кораблів та інші), розроблено та випробувано декілька композицій низько- та високотемпературних пастоподібних палив, для підтвердження основних проектних технічних рішень розроблено, виготовлено та проведено холодні та вогневі стендові випробування дослідного зразка (моделі) РДУПП, більшість прийнятих технічних рішень підтверджено вогневими випробуваннями.

Такі двигуни (РДПП) можуть знайти широке застосування в якості маршових двигунів для верхніх ступенів ракет-носіїв, добре проявлять себе в якості двигунів маневрування, а також як двигуни м'якої посадки космічних апаратів. Застосування РДПП 3 можливістю багаторазового запуску в якості виконавчих органів системи управління під час вирішення низки завдань дозволяс зменшити габаритно-масові характеристики космічних розгінних блоків або космічних апаратів, а також дозволить збільшити точність виведення КА на орбіту. Але найбільш якісно вони проявлять себе як двигуни маневрування i стикування в космосі. У такому амплуа їх можна застосовувати на космічних кораблях, які використовуються для збору космічного сміття, тобто там, де потрібна велика кількість точних маневрів. 
Таким чином, на сьогодні в Україні створено унікальний науково-технічний доробок, який достатній для розробки низки нових ракетних двигунних установок різного призначення. У зв'язку 3 цим $€$ повні підстави вважати роботи на Дніпропетровщині зі створення регульованих РДУПП як новий напрямок у світовому ракетному двигунобудуванні. Основні результати робіт за даним напрямком опубліковані в $[1-5 ; 9 ; 11 ; 12$; $16-22 ; 24 ; 25]$.

Висновки. Кафедра двигунобудування фізико-технічного факультету Дніпровського національного університету ім. О. Гончара за більш як шість десятиліть свого існування, окрім підготовки тисяч висококласних спеціалістів для ракетнокосмічної галузі, оборонної промисловості, енергетики та інших напрямків народного господарства, відома своїми науковими школами, фундаментальними та прикладними науковими дослідженнями на теренах багатьох країн світу. Співробітниками кафедри двигунобудування проводяться актуальні та перспективні наукові дослідження в галузі ракетно-космічної техніки та енергетики, в тому числі: рідинних, твердопаливних, детонаційних, пастоподібних, комбінованих ракетних двигунів, їх систем постачання палива, надійності, випробувань та тепломасообмінних процесів 3 фазовими перетвореннями палив та робочих тіл.

\section{Бібліографічні посилання}

1. Бондаренко С.Г., Петренко Р.М., Сердюк А.І. Екологічно чисте пастоподібне паливо та перспективи його застосування в ракетно-космічній техніці. Проблемы высокотемпературной техники. Днепропетровск : Акцент ПП, 2014. С. 20-32.

2. Бондаренко С.Г., Хорольский П.Г., Адамчик Л.В. К оценке энерговесовой эффективности ракетных двигателей на пастообразном топливе с глубоким дросселированием. Авиационно-космическая техника и технология. Харьков : НАУ «ХАИ». 2008. № 7(54). С. 148-150.

3. Бондаренко С.Г., Коваленко Н.Д. Особенности отработки высотных ракетных двигательных установок пастообразного топлива с регулируемым вектором тяги. Авиационно-космическая техника и технология. Харьков : НАУ «ХАИ». 2010. № 4/71. С. 84-90.

4 Бондаренко С.Г., Дронь М.М., Дубовик Л.Г. Ракетні двигунні установки міжорбітальних транспортних апаратів в умовах запобігання засміченню навколоземного простору. Дніпро : Вид-во Лipa, 2016. 232 c.

5. Бондаренко С.Г., Габринец В.А. Эффективность применения гидрида алюминия для ракетно-космических двигателей на пастообразном топливе. Авиачионно-космическая техника $и$ технология. Харьков : НАУ «ХАИ», 2015. № 4(121). C. 96-103.

6. Габрінець В.О., Подольчак С.М. Вероятностный анализ взаимодействия системы аварийной защиты и ракетного двигателя при стендовых испытаниях. Проблемы высокотемпературной техники: сб. науч. тр. Днепропетровск : Пороги, 2013. C. 25-31.

7. Габринец В.А., Марченко О.Л. Влияние вибраций на гидродинамические процессы двухфазного потока в трактах ЖРД. Проблемы высокотемпературной техники: сб. науч. тр. Дніпропетровськ, Акцент ПП, 2014. С. 37-42.

8. Габрінець В.О., Подольчак С.М. Оценка эффективности выбранной программы ускоренных испытаний. Авиационно-космическая техника $и$ технология: научно-техн. журнал. Харьков : ХАИ. 2015. № 1 (118). С.103-107.

9. Дронь М.М. Хорольський П.Г., Хитько А.В., Бондаренко С.Г., Безуглий В.А., Дубовик Л.Г. Технічні засоби для очищення навколоземного простору від космічного сміття : навч. посіб. Дніпропетровськ : Вид-во Ліра, 2013. $128 \mathrm{c}$.

10. Золотько О.Є. Коваленко М.Д., Стрельніков Г.О., Мороз Ю.І., Золотько О.В., Сосновська О.В. Аналіз впливу параметрів зовнішнього середовища на імпульсні характеристики детонаційного двигуна. Проблемы высокотемпературной техники. Дніпропетровськ : Вид-во ДНУ, 2014. С. 79-87. 
11. Іванченко А.М. Особливості ракетної рушійної установки на пастоподібному паливі. Космічна наука $i$ технологія. 1999. Т 5. № 4. С. 1-10.

12. Майданюк Д.В., Бондаренко С.Г., Иванченко А.Н., Павленко Д.В. Анализ эффективности применения маршевой двигательной установки на унитарном пастообразном топливе на верхних ступенях ракет-носителей лёгкого класса. Авиаиионно-космическая техника и технология. Харьков : НАУ ХАИ, 2009. № 9/66. С. 95-99.

13. Мисюра В.И., Овсянников Б.В., Присняков В.Ф. Дисковые насосы. Москва : Машиностроение, 1986. 112 с.

14. Секретний підрозділ галузі: Нариси історії фізико-технічного інституту Дніпропетровського національного університету / Редкол. М. В. Поляков (керівник). Дніпропетровськ : Вид-во Дніпропетр. ун-ту, 2001. 376 с. ISBN 966551-075-4.

15. Сосновська О.В., Золотько О.С., Мороз Ю.І., Золотько О.В. Аналіз впливу конструктивних параметрів ежекторного сопла на характеристики детонаційного двигуна. Механіка гіроскопічних систем. Вип.30. Київ, 2015. С. 62-72.

16. Трунов И.А., Иванченко А.Н., Бондаренко С.Г. О возможности использования пастообразного топлива в ракетных двигательных установках различного назначения. Вісник Дніпропетровського університету. Серія «Ракетно-космічна техніка». 2005. Вип. 16, № 8. C. 87-91.

17. Хорольский П.Г., Бондаренко С.Г. Оценка эффективности одного варианта применения глубокого гибкого регулирования тяги для выведения полезной загрузки. Вестник двигателестроения. Запорожье: ОАО «Мотор Сич», 2010. № 2. С. 79-81.

18. Якушенко В.Г., Майданюк Д.В., Бондаренко С.Г. Дослідження масової ефективності використання двигунної установки на унітарному пастоподібному паливі на верхній ступені ракети-носія «Циклон-4». Системне проектування та аналіз характеристик аерокосмічної техніки. Дніпропетровськ : Вид-во Ліра, 2015. Т. XIX. C. 178-183.

19. Rocket propulsion using unitary paste-like propellant. Experimental investigation of paste-like propellant and results of PRM fire tests (IAC-10.C4.1.9) [Text] / S.G. Bondarenko, V.I. Eliseev, Yu.V. Protsan, N.V. Masliany, E.B. Ustimenko, T.A. Mayorskaya, V.P. Babitskiy, A.F. Kurochkin, S.F. Lyagushyn, L.I. Podkamennaya, A.B. Surovtsev, A.A. Golenko, N.K. Savytskaya, A.I. Stepchenko, A.I. Serdyuk. Proc. of 61-th International Astronautical Congress, 27 September - 1 October 2010. Prague, Czech Republic. Prague, 2010. $27 \mathrm{p}$.

20. Slurry-propellant rocket propulsion. New design solutions for displacing gasgenerator and reliable multistart / S.G. Bondarenko, A.I. Serdyuk, Yu.V. Protsan, M.D. Kovalenko, G.O. Strel'nikov. Proc. of 63-rh International Astronautical Congress, 1-5 October 2012. Naples, Italy. Naples, 2012.9 p.

21. The investigation of thermal and gas dynamic processes in the combustion chamber of the rocket engine using slurry fuel / Sergii Bondarenko, Andrii Dreus, Katerina Lysenko. Proceedings of the Institution of Mechanical Engineers. Part G: Journal of Aerospace Engineering. 2017. First published date: April11-2017. 8 p.

22. Deep Regulation and Reusable Rocket Propulsion Using Premixed Slurry Propellant. A.M. Ivanchenko, S.G. Bondarenko, Y.V. Protsan, Sh.A. Wilson. Journal of Propulsion and Power. 2012. Vol. 28. No. 5. P. 869-875.

23. About the complex influence of vibrations and gravitational fields on serviceability of heat pipes in composition of space-rocket systems / K. Prisniakov, O. Marchenko, Y. Melikaev, V. Kravetz, Y. Nikolaenko, V. Prisniakov. Acta Astronautica. 2004. T. 55. №. 3-9. C. 509518.

24. Rodrigo C.G., Бондаренко С.Г. Дросселируемый ракетный двигатель на пастообразном топливе для космического апарата. Вісник Дніпропетровського університету. Серія: «Ракетно-космічна 
техніка». 2012. Т. 20. № 4. Вип. 16. Т. 2. С. $3-14$.

25. Serdyuk A.I., Protsan Yu.V., Bondarenko S.G. Slurry-propellant rocket propulsion. Eco-safety and new power opportunities. Tests of new propellants (IAC-
2013, C4.3,11). Proc. of 64-th International Astronautical Congress, 23-27 September 2013, Beijing, China. - Beijing, 2013. 9 p.

\title{
РАЗРАБОТКА И ИССЛЕДОВАНИЕ МЕТОДОВ НЕЙТРАЛИЗАЦИИ СОРБЕНТА, ЗАГРЯЗНЕННОГО ПАРАМИ КОМПОНЕНТОВ РАКЕТНОГО ТОПЛИВА
}

\author{
С.А. Кудринский, Г.Л. Поздеев, Л.В. Муравлева, Т.В. Гуназа \\ Государственное предприятие «КБ «Южное», ул. Криворожская, 3, г. Днепр, 49008, \\ Украина, е-mail:info@yuzhnoye.com
}

Розглянуто питання нейтралізації твердих відходів - сорбенту, насиченого парами висококиплячих компонентів ракетного палива (тетраоксид діазоту - окислювач, несиметричний диметилгидразин - пальне). Експериментально перевірено відомі і розроблені оригінальні методи нейтралізації сорбенту, забрудненого парами компонентів ракетного палива. Представлено результати стендових випробувань методів нейтралізації.

Ключові слова: сорбент, нейтралізація, методи нейтралізації, компоненти ракетного палива.

The paper discusses the issues for neutralization of solid waste - sorbent saturated with vapors of highboiling propellants (dinitrogen tetraoxide - oxidizer, nonsymmetrical dymethylhydrazine - fuel). The original methods of neutralizing the sorbent, contaminated with vapors of propellants, have been developed and the known methods have been experimentally checked. The neutralization methods bench test results have been presented.

Keywords: sorbent, neutralization, neutralization methods, propellants.

В работе рассмотрены вопросы нейтрализации твердых отходов - сорбента, насыщеного парами высококипящих компонентов ракетного топлива (тетраоксид диазота - окислитель, несимметричный диметилгидразин - горючее). Экспериментально проверены известные и разработаны оригинальные методы нейтрализации сорбента, загрязненного парами компонентов ракетного топлива. Показаны результаты стендовых испытаний методов нейтрализации. топлива.

Ключевые слова: сорбент, нейтрализация, методы нейтрализации, компоненты ракетного

Введение. В составе систем, агрегатов и средств нейтрализации паров и промстоков токсичных высококипящих компонентов ракетного топлива КРТ (тетраокси диазота - окислитель, несимметричный диметилгидразин - горючее) наземного комплекса применяются «кассетные» и «полочные» фильтрыпоглотители для нейтрализации и обезвреживания паров и дренажных газов КРТ до предельно допустимых концентраций (ПДК). В фильтрахпоглотителях используется наполнитель сорбент, который представляет собой вещество на основе активированного угля, имеющее пористую структуру, обладающую способностью хорошо адсорбировать пары КРТ [1].
Постановка задачи. После насыщения парами КРТ сорбент подлежит нейтрализации и последующей утилизации. Для реализации указанной задачи поставлена цель отработки существующих химических и физических методов нейтрализации сорбента, а также последующей утилизации в условиях космодрома.

Экспериментальная часть. На стендах ГП «КБ «Южное» проводились работы по нейтрализации сорбента, загрязненного окислителем и горючим, с использованием как физического (жидкостного) [2], так и химического методов [3].

$\begin{array}{cr}\text { При нейтрализации } & \text { сорбента, } \\ \text { загрязненного окислителем, } & \text { сорбент }\end{array}$

(C) Кудринский С.А., Поздеев Г.Л., Муравлева Л.В., Гуназа Т.В., 2018 